\title{
„DUSZPASTERSKIE NAWRÓCENIE" PREZBITERÓW DROGĄ DO ODNOWY DUSZPASTERSTWA PARAFIALNEGO
}

Streszczenie. Parafia stanowi podstawową wspólnotę Kościoła. Od niej w dużej mierze zależy życie Kościoła lokalnego. Współczesne nauczanie Kościoła przypisuje parafii duże znaczenie i stwierdza, że nie jest ona strukturą przestarzałą. Równocześnie wskazuje na ciągłą potrzebę odnowy parafii. Dokonuje się to w znacznym stopniu poprzez odnowę parafialnego duszpasterstwa. Ponieważ główna odpowiedzialność za to duszpasterstwo spoczywa na prezbiterach a zwłaszcza na proboszczu, to od nich w dużej mierze zależy skuteczność tej odnowy. Niniejszy artykuł ukazuje potrzebę „duszpasterskiego nawrócenia” prezbiterów jako konieczny warunek skutecznej odnowy parafialnego duszpasterstwa.

Słowa kluczowe: duszpasterskie nawrócenie; prezbiter; parafia; duszpasterstwo.

Abstract. The "Pastoral Conversion" of the Presbyters as a Way to the Renewal of the Parish Pastoral Care. The parish is the basic community of the Church. The life of the local Church depends to a large extent on it. The contemporary teaching of the Church attributes great importance to the parish and states that it is not an outdated structure. At the same time, he points to the constant need to renew the parish. This is done to a large extent by the renewal of the parish pastoral care. Since the main responsibility for this pastoral care rests with the priests and especially at the parish priest, the effectiveness of this renewal depends largely on them. This article shows the need for 
the "pastoral conversion" of presbyters as a necessary condition for the effective renewal of the parish pastoral work.

Key words: pastoral conversion; presbyter; parish; pastoral care.

Odnowa parafii musi uwzględniać zarówno jej teologiczną tożsamość - „prawdziwe oblicze parafii”, jak i uwarunkowania, w których realizuje swoją misję. Parafię tworzą wierni świeccy i wyświęceni kapłani, spośród których szczególne zadanie ma proboszcz. Reprezentuje on biskupa diecezji i jest „hierarchicznym ogniwem łączącym parafię z całym Kościołem partykularnym” (ChL 26). Posoborowe prawodawstwo kościelne definiuje parafię jako „określoną wspólnotę wiernych, utworzoną w sposób stały w Kościele partykularnym, nad którą pasterską pieczę, pod władzą biskupa diecezjalnego, powierza się proboszczowi jako jej własnemu pasterzowi”2. Odnowa duszpasterska parafii zależy zatem w dużej mierze od prezbiterów, a zwłaszcza od proboszcza. W niniejszym zostanie ukazana potrzeba „duszpasterskiego nawrócenia” prezbiterów jako konieczny warunku odnowy duszpasterstwa w parafii.

\section{PARAFIA W KRYZYSIE}

Kierowane przez papieża Franciszka do Kościoła wezwanie do „duszpasterskiego nawrócenia”" ${ }^{3}$ wypływa z ewangelicznego rozeznania współczesnego „kairosu ewangelizacyjnego”. Ewangelizacyjny kairos wiąże się niewątpliwie z pojęciem kryzysu, rozumianym jednak nie jako upadek czy regres, ale zgodnie z etymologią słowa kryzys (greckie krinein) oznaczającego: sądzić, rozróżniać, oddzielać. W tym kontekście stwierdzenie, że wiara religijna przechodzi obecnie kryzys, należy interpretować w tym znaczeniu, że w wyniku konfrontacji ze współczesnym światem jej ak-

${ }^{1}$ Jan Paweł II, Adhortacja apostolska Christifideles laici o powołaniu i misji świeckich w Kościele i świecie (1998), nr 46 (dalej skrót: ChL).

2 Por. Kodeks Prawa Kanonicznego (1983), kan. $515 \$ 1$.

3 Franciszek, Adhortacja apostolska Evangelii gaudium o głoszeniu Ewangelii we współczesnym świecie (2013), nr 25 (dalej skrót: EG). 
tualne oblicze zostało zakwestionowane, wezwane do osądzenia siebie, do rozróżnienia tego, co w sferze religijnej jest zasadnicze i uniwersalne od tego, co ma charakter drugorzędny i przejściowy. Wymaga to wejścia wspólnot kościelnych „w zdecydowany proces rozeznania, oczyszczenia i reformy" (EG 30).

Kryzysy w Kościele są czymś normalnym: Kościół jest sakramentem zbawienia w świecie, ale nośnikiem tej łaski są grzeszni ludzie. Ci ludzie muszą stać się penitentami - muszą się nawracać i to nie raz, nie dwa, ale stale, do końca życia. Niezbędne jest ciągłe oczyszczanie Kościoła. Można za Wojciechem Giertychem OP wyodrębnić „oczyszczenie bierne” - prowokowane przez Boga - i „oczyszczenie czynne” - podejmowane przez ludzi Kościoła.

Jak pokazuje historia biblijnego Hioba kryzys bywa niekiedy wymuszany przez samego Boga. W teologii nazywa się to oczyszczeniem biernym. Oczyszczenie czynne polega na tym, że człowiek sam widzi swoje grzechy i próbuje coś zmienić w życiu. Owoce tego bywają jednak marne. Dlatego Pan Bóg sam wkracza i przeprowadza człowieka przez trudny okres. Wtedy mówimy o oczyszczeniu biernym ${ }^{5}$.

Bóg oczyszcza wtedy, gdy owoce „czynnego oczyszczenia” są słabe. I tak jest obecnie. Takie zjawiska, jak: nagłośniona medialnie pedofilia, rozwody i powtórne małżeństwa, antyklerykalizm, ateizm praktyczny, odchodzenie od praktyk religijnych, regres powołaniowy itp. - to główne symptomy obecnego kryzysu, które należy interpretować kairologicznie poprzez „ewangeliczne rozeznanie”, jako „znaki czasu”.: „Jeśli się nie nawrócicie, wszyscy podobnie zginiecie” (Łk 13, 3).

Już Paweł VI zwrócił uwagę, że ewangeliczne wezwanie do nawrócenia (por. Mk 1, 15) jest skierowane nie tylko do pojedynczych osób, ale odnosi się także do całej sieci relacji, które są dziełem określonego stylu pasterskiej posługi Kościoła. Znalazło to między innymi wyraz w jego programowej encyklice Ecclesiam suam, w której z naciskiem zaznaczył,

${ }^{4}$ Por. M. Polak, Od teologii do eklezjologii pastoralnej. Zagadnienia fundamentalne, Poznań 2014, s. 36-38.

${ }_{5}$ Program nieużywany. Z prof. Wojciechem Giertychem OP, Teologiem Domu Papieskiego rozmawia Roman Bielecki OP, „W Drodze” 2018 (542) 10, s. 46-47. 
że „Kościół szuka z mężnym i pełnym zapału odruchem swojej własnej odnowy, czyli naprawy tych błędów [...], które mu jakby w zwierciadle jego wzoru - Chrystusa - wytyka i piętnuje jego własne sumienie"6. Wraz z pontyfikatem Jana Pawła II wzrosła świadomość, że eklezjalne nawrócenie musi dotknąć także ewangelizacji ${ }^{7}$. W encyklice Veritatis splendor czytamy, że postulat „nowej ewangelizacji” dopiero w kontekście Chrystusowego wezwania do nawrócenia „ujawnia swą autentyczność i równocześnie wyzwala cały swój dynamizm misyjny"8. Zapewne z tej racji Jan Paweł II, inaugurując w 1992 roku IV Konferencję Ogólną Episkopatu Ameryki Łacińskiej (CELAM), obradującą w Santo Domingo na temat: „Nowa ewangelizacja, postęp człowieka, kultura chrześcijańska”, stwierdził: „Wezwanie do nowej ewangelizacji jest przede wszystkim wezwaniem do nawrócenia”. Termin „duszpasterskie nawrócenie” po raz wtóry pojawił się w 2007 roku w identycznym dokumencie VII Konferencji Ogólnej Episkopatu Ameryki Łacińskiej w brazylijskiej Aparecidzie ${ }^{10}$. Latynoamerykański rodowód papieża Franciszka sprawił, że ów termin znalazł się w adhortacji apostolskiej Evangelii gaudium, ubogacając nie tylko język kościelnego Magisterium, ale i ideę „nowej ewangelizacji” (por. EG 14) ${ }^{11}$. „Duszpasterskie nawrócenie” dotyczy zarówno aktualnych struktur kościelnych, obrzędów i zwyczajów, jaki i treści oraz sposobu przepowiadania prawd wiary, a także, jeśli nie przede wszystkim, prezbiterów odpowiedzialnych za parafialne duszpasterstwo. Cały ten proces ma prowadzić do tego, aby wszystkie elementy posługi pasterskiej Kościoła „stały się odpowiednią drogą bardziej dla ewangelizowania współczesnego świata niż dla zachowania stanu rzeczy” (por. EG 27. 41. 43). Papież Franciszek

${ }^{6}$ Paweł VI, Encyklika Ecclesiam suam o drogach, którymi Kościół Katolicki powinien kroczyć w dobie obecnej przy pełnieniu swej misji (1964), nr 11.

${ }^{7}$ Jan Paweł II, List apostolski Tertio Millennio adveniente (1994), nr 31-36 (dalej skrót: TMA).

${ }^{8}$ Jan Paweł II, Encyklika Veritatis splendor o niektórych podstawowych problemach nauczania moralnego Kościoła (1993), nr 107 (dalej skrót: VS).

9 Por. Jan Paweł II, Nowa ewangelizacja, postęp człowieka, kultura chrześcijańska (12.10.1992), „L'Osservatore Romano” wyd. polskie 13 (1992), nr 12, s. 22.

${ }^{10}$ VII Konferencja Ogólna Episkopatu Ameryki Łacińskiej, Aparecida. Jesteśmy uczniami i misjonarzami Jezusa Chrystusa, Warszawa 2014, nr-y 365-372.

${ }^{11}$ Por. M. Polak, Prezbiterologia pastoralna. Pastoralna tożsamość wspótczesnego prezbitera, Poznań 2016, s. 74. 
wielokrotnie wskazywał na potrzebę przebudowy struktur kościelnych. Niekiedy bowiem mogą one „doprowadzić do krępowania dynamizmu ewangelizacyjnego, zaś dobre struktury są użyteczne tylko wtedy, kiedy nieustannie kieruje nimi, wspiera i osądza je życie" (EG 26) ${ }^{12}$.

Reformę struktur, wymagającą odnowy duszpasterskiej - naucza Franciszek - można zrozumieć jedynie w tym sensie: należy sprawić, by stały się one wszystkie bardziej misyjne, by duszpasterstwo zwyczajne we wszystkich swych formach rozszerzało swój zasięg i było bardziej otwarte, by doprowadziło zaangażowanych w nie ludzi do przyjęcia stałej postawy «wyjścia» i w ten sposób sprzyjało udzieleniu pozytywnej odpowiedzi ze strony tych wszystkich, którym Jezus ofiaruje swoją przyjaźń (EG 27).

Do nawrócenia duszpasterskiego struktur należałoby odnieść nauczanie Jana Pawła II, które zawarł w adhortacji Reconciliatio et paenitentia, dotyczące grzechu osobistego, społecznego i struktur grzechu. Brzmi ono następująco:

Na dnie każdej sytuacji grzechu znajdują się zatem zawsze osoby, które grzech popełniają. Jest to tak dalece prawdziwe, że gdy dana sytuacja może być zmieniona pod względem strukturalnym i instytucjonalnym siłą prawa lub - jak często się niestety zdarza - prawem siły, to w rzeczywistości taka zmiana okazuje się niepełna, krótkotrwała, a w ostateczności daremna i nieskuteczna - i nawet przynosząca odwrotny skutek - jeśli nie towarzyszy jej nawrócenie osób bezpośrednio czy pośrednio za tę sytuację odpowiedzialnych ${ }^{13}$.

„Nawrócenie duszpasterskie” o tyle będzie skuteczne, o ile reforma struktur wynikać będzie z nawrócenia osób odpowiedzialnych za misję pastoralną Kościoła. Gdy chodzi o prezbiterialną odpowiedzialność w tym zakresie, szczególną uwagę trzeba zwrócić na elementarną strukturę pastoralną, jaką jest parafia, bo to właśnie w jej instytucjonalnych ramach prezbiterzy jako „pilni współpracownicy stanu biskupiego, jego pomoc

12 Por. T. Wielebski, Nawrócenie pastoralne i duszpasterstwo misyjne w Polsce, w: Polska krajem misyjnym? 1050 lat chrześcijaństwa w Polsce, red. P. Ochotny, M. J. Tutak, T. Wielebski, Warszawa 2016, s. 131-133.

${ }^{13}$ Jan Paweł II, Adhortacja apostolska Reconciliatio et paenitentia o pojednaniu i pokucie w dzisiejszym posłannictwie Kościoła (1984), nr 16. 
i narzędzie" są "powołani do służenia Ludowi Bożemu”14. Formułowane już od dłuższego czasu wezwania do rewizji odnowy parafii nie przyniosły - jak dotąd - zadowalających rezultatów, czego jednym z powodów jest niewątpliwie nie w pełni podjęte przez parafialnych prezbiterów wezwanie do „duszpasterskiego nawrócenia” ${ }^{15}$.

\section{PREZBITER W KRYZYSIE}

Kairologiczne aspekty pastoralnej misji prezbitera pozostają $\mathrm{w}$ integralnym związku z historycznymi i cywilizacyjnymi przemianami, jakie dokonują się w otaczającym nas świecie, i jako takie zakładają adaptacyjny wysiłek w stosunku do nowych wyzwań. Postulowana adaptacja jest $\mathrm{z}$ reguły procesem powolnym i długofalowym. Związane $\mathrm{z}$ tym nieuchronne „opóźnienia” rodzą zjawisko, które określa się mianem kryzysu. Kryzys „prezbiterialnej tożsamości”, jaki obecnie przeżywamy, nie bez racji uważa się za niezwykle złożony i głęboki, jako że procesy przemian cywilizacyjnych uległy, zwłaszcza w ostatnim półwieczu, gwałtownemu przyspieszeniu, upowszechnieniu i radykalizacji. Rodzące się na tym podłożu trudności adaptacyjne zaowocowały w środowisku prezbiterów narastającym niepokojem, niepewnością, dezorientacją, nierzadko również moralną i pastoralną demobilizacją. Kairologiczna analiza posoborowego „kryzysu prezbiterialnej tożsamości” ${ }^{16}$ odwołuje się przede wszystkim do wypowiedzi kościelnego Magisterium ${ }^{17}$, gdyż „ewangeliczne rozeznanie” jest dziełem całego Kościoła podejmowanym w oparciu o charyzmat „nadprzyrodzonego zmysłu wiary” (por. LG 12), zaofiarowany przez Ducha Świętego ogółowi wiernych wedle właściwej każdemu odpowiedzialności ${ }^{18}$.

14 Sobór Watykański II, Konstytucja dogmatyczna Lumen gentium o Kościele (1964), nr 28 (dalej skrót: LG).

15 Por. T. Makowski, Postulat odnowy parafii w kontekście pastoralnych wyzwań nowej ewangelizacji, „Studia Gnesnensia” 21 (2007), s. 169-222.

${ }_{16}$ Por. Jan Paweł II, Adhortacja apostolska Pastores dabo vobis o formacji kapłanów we współczesnym świecie (1992), nr 11 (dalej skrót: PDV).

17 Por. K. Kaproń, Kościót, który się nawraca, „Więź” 56 (2013) 4, s. 84-90.

18 Por. M. Polak, Prezbiterologia, s. 39-47. 
Głównym przejawem posoborowego „kryzysu tożsamości prezbitera" - zwłaszcza w Europie Zachodniej i w Stanach Zjednoczonych Ameryki Północnej - były masowe rezygnacje z posługi pasterskiej. W latach osiemdziesiątych ubiegłego stulecia zarysował się również wyraźny wzrost ilości księży rezygnujących z posługi pasterskiej w krajach Europy Wschodniej, między innymi w Polsce ${ }^{19}$. Z empirycznych badań tej kryzysowej sytuacji wynika, że najczęstszym motywem podejmowania tak radykalnych decyzji są problemy związane z celibatem i samotnością ${ }^{20}$. Przyczyny księżowskich dezercji są jednakże dużo głębsze i bardziej zróżnicowane. Tym, co cechuje chrześcijańską duchowość, jest całkowite oddanie się Bogu na właściwej każdemu drodze życia - obojętnie, czy to będzie małżeństwo, konsekracja zakonna czy służba pasterska - a w dalszej konsekwencji wierność zakładająca poświęcenie. To poświęcenie, jeśli jest wyrazem autentycznej wiary, nigdy nie oznacza osobowościowej destrukcji. Pojawianie się nihilistycznej retoryki w wyznaniach niektórych eks-księży - uchwytne choćby w tym, że dana osoba nie potrafi odróżnić pojęcia ofiary od samoudręczenia, a wyrzeczenia od stanu regresu - należy traktować jako niebezpieczną oznakę zagubienia. Niestety takie zagubienie to nader charakterystyczna cecha współczesnej epoki, promującej indywidualizm, hedonizm, praktyczny i egzystencjalny ateizm oraz mentalność konsumpcyjną (por. PDV 7) ${ }^{21}$.

Kolejnym przejawem kryzysu instytucji prezbiteratu jest poważne zmniejszenie się liczby kandydatów do pasterskiego posługiwania. W Polsce mimo znacznej powołaniowej progresji w okresie po II wojnie światowej odnośny wskaźnik liczby wiernych przypadających na jednego kapłana w ciągu minionego półwiecza utrzymuje się na poziomie bliskim 2000 wiernych na jednego pasterza. Taki stan rzeczy w najbliższym czasie będzie się zmieniał, bo od kilkunastu już lat również w polskich seminariach kleryków jest coraz mniej. Według danych statystycznych liczba alumnów w diecezjalnych seminariach duchownych w Polsce w latach

19 Por. J. Baniak, Rezygnacja z kapłaństwa i wybór życia małżeńsko-rodzinnego przez księży rzymskokatolickich w Polsce, Kraków 2001, s. 71-114.

${ }^{20}$ Por. tenże, Czynniki kryzysu tożsamości kapłańskiej wśród księży rzymskokatolickich $w$ Polsce, „Teologia Praktyczna” 8 (2007), s. 234-235.

${ }^{21}$ Por. G. Strzelczyk, Odejścia, wierność i oślica Balaama, „Więź” 50 (2007) 6, s. $32-39$. 
1990-2016 spadła z 5436 do 2300, czyli w okresie 25 lat zmniejszyła się o blisko $60 \%{ }^{22}$.

Kościelne Magisterium podejmując trud „ewangelicznego rozeznania” kryzysu prezbiterialnej tożsamości, nie mogło w końcu nie poddać wnikliwej analizie nagłośnionego w ostatnich latach przez media komunikacyjne problemu obyczajowych i moralnych nadużyć duchowieństwa. Wiadomo, że pasterze Kościoła - podobnie jak ogół wiernych, którym usługują - nie są wolni od grzechu. Niemniej niektóre czyny muszą prowadzić do „zawieszenia w posłudze”, a nawet do kanonicznej redukcji ad statum laicalem. Z całą pewnością wchodzi to w grę w sytuacji życia w trwałym konkubinacie, czynnie praktykowanego homoseksualizmu, a nade wszystko seksualnego wykorzystywania nieletnich. Zwłaszcza ta ostatnia sytuacja jest nader bulwersująca i zawstydzająca ${ }^{23}$.

Grzech pedofilii jest nie tylko poważnym nieładem moralnym, ale i przestępstwem karanym przez prawo cywilne. Dlatego przełożonym kościelnym nie wolno w imię fałszywie pojętej troski o ilościowy potencjał „robotników na żniwie Pańskim”, bądź o ich społeczny prestiż, ukrywać faktów, osłaniać sprawców, a nade wszystko ignorować cierpienia ofiar. Oczywiście molestowanie nieletnich zdarza się nie tylko w środowisku kapłańskim, a medialne informacje na ten temat $\mathrm{z}$ reguły cechuje ideologicznie zabarwiona jednostronność i agresywny antyklerykalizm, tym niemniej fakt, że w gronie osób dopuszczających się nadużyć seksualnych znaleźli się również duchowni, powinien być dla Kościoła traumatycznym wstrząsem, nie dopuszczającym jakiejkolwiek formy kamuflażu²4. Benedykt XVI wyznał z bólem:

${ }^{22}$ Dane za: Instytut Statystyki Kościoła Katolickiego SAC, Annuarium Statisticum Ecclesiae in Polonia AD 2018, oprac. W. Sadłoń, Warszawa 2018: http://iskk.pl/images/ stories/Instytut/dokumenty/Annuarium_Statisticum_2018.pdf; Instytut Statystyki Kościoła Katolickiego SAC, Główny Urząd Statystyczny, Kościół Katolicki w Polsce 1991-2011, Warszawa 2014: file://C:/Users/MP/Downloads/rs_kosciol_katolicki_1991-2011.pdf [dostęp: 10.12.2018].

${ }^{23}$ Por. D. Martin, Krzywda, nadzieja, uzdrowienie. Osobista droga biskupa przez skandale seksualne, „Więź” 54 (2011) 8-9, s. 24-35.

${ }^{24}$ Peter Seewald w rozmowie z Benedyktem XVI zauważył, że według kryminologa Christiana Pfeiffera tylko 0,1\% sprawców przestępstw seksualnych pochodzi z kręgu ludzi związanych zawodowo z Kościołem katolickim, a w świetle amerykańskiego 
to szczególnie ciężki grzech, gdy ktoś, kto ma pomagać ludziom w drodze do Boga, komu na tej drodze powierza się dziecko, zamiast prowadzić je do poznania Boga, molestuje je i od Boga odwodzi. Przez to wiara jako taka staje się nieprzekonująca, a Kościół nie może wiarygodnie przedstawiać się jako ten, który głosi Jezusa Chrystusa ${ }^{25}$.

W specjalnym liście pasterskim, zaadresowanym do katolików Irlandii, papież nazwał to zawstydzające doświadczenie „bolesną raną” Kościoła, która wymaga skutecznego zaleczenia ${ }^{26}$. Benedykt XVI, jeszcze jako prefekt Kongregacji Nauki Wiary, w 2001 roku doprowadził do wypracowania kanonicznych norm postępowania wobec osób duchownych podejrzanych o kontakt seksualny z nieletnimi. W maju 2010 roku ta sama Kongregacja uzupełniła te normy, między innymi wydłużając okres przedawnienia skargi dotyczącej przestępstwa z 10 do 20 lat. Rok później Stolica Apostolska skierowała list okólny do wszystkich Konferencji Episkopatu, zobowiązujący je do opracowania wytycznych odpowiadających sytuacji poszczególnych krajów i uwzględniających obowiązujące normy ${ }^{27}$. Oczywiście, same regulacje prawne nie wystarczą. Niezbędne jest ponadto zastosowanie skutecznych środków prewencyjnych, a także pozytywnych działań stwarzających duchowy klimat, umożliwiający dogłębną analizę tych czynników, które znalazły się u źródeł prezbiterialnych nadużyć seksualnych wobec nieletnich. Według Benedykta XVI najistotniejsze przyczyny tych wykroczeń można sprowadzić do następujących: niewłaściwe procedury stosowane przy określaniu, czy kandydaci do prezbiteratu speł-

raportu rządowego z 2008 roku udział księży uwikłanych w przypadki pedofilii to 0,05\%. Stąd medialna wrzawa na temat „skandalu pedofilii w Kościele”, zatracając właściwą miarę, wydaje się mało wiarygodna. Papież w odpowiedzi stwierdził, co następuje: „Nie można było przeoczyć, że nie tylko czyste pragnienie prawdy napędzało rewelacje prasy, ale także była w tym radość ze skompromitowania i zdyskredytowania Kościoła. Pomimo to zawsze musi być jasne, że o ile jest to prawda, musimy być wdzięczni za każde wyjaśnienie”. Por. P. Seewald, Światłość świata. Papież, Kościół i znaki czasu, tłum. P. Napiwodzki, Kraków 2011, s. 39 i 42.

25 Tamże, s. 37.

${ }^{26}$ Benedykt XVI, List pasterski do katolików Irlandii (19.03.2010), „L'Osservatore Romano" wyd. polskie 31 (2010) nr 5, s. 7.

27 Por. M. Kelm, Jak przerwać spirale grzechu? Prawo kościelne wobec pedofilii duchownych, „Więźz 54 (2011) 8-9, s. 55-62. 
niają konieczne do tego warunki; niewystarczająca formacja w seminariach duchownych; społeczna tendencja do przychylniejszego traktowania duchowieństwa i innych osób spełniających kierownicze stanowiska; źle pojmowana troska o dobre imię Kościoła i o to, by unikać skandali, czego skutkiem było niestosowanie obowiązujących kar kanonicznych i brak ochrony godności każdej osoby ${ }^{28}$. Papieska konkluzja powyższej diagnozy jest następująca: „Należy bezzwłocznie działać, by rozwiązać te problemy, które spowodowały tak tragiczne następstwa w życiu ofiar nadużyć i ich rodzin, a także przysłoniły światło Ewangelii takim mrokiem, jakiego nie znały nawet wieki prześladowań" 29 .

Kapłańskie skandale obyczajowe i dezercje, a także dramatyczny regres powołaniowy, zaostrzyły i pogłębiły adaptacyjny kryzys związany $\mathrm{z}$ wprowadzeniem w życie pastoralnej odnowy zainicjowanej przez II Sobór Watykański. Wspomniano już, że w posoborowym okresie znaczną część duchowieństwa dotknęła jakaś postać niepokoju, niepewności i dezorientacji, zarówno w przedmiocie pasterskiej posługi, jak i powiązanego z nią życia. Niektórzy teologowie bowiem i sprzymierzeni z nimi dziennikarze, zakosztowawszy medialnego rozgłosu i traktując siebie niemal za równoległe - eksperckie - Magisterium, prezentowali Sobór tak, że można było odnieść wrażenie, iż „W Kościele nie ma nic stałego, że wszystko podlega rewizji” ${ }^{30}$.

„Nie ukrywajmy - naucza Jan Paweł II - że istnieją trudności. Są one liczne i poważne. Lecz przezwycięża je nasza nadzieja, nasza wiara, że nic nie może zastąpić posługi kapłańskiej w życiu Kościoła i świata” (PDV 10). Przytoczony fragment adhortacji apostolskiej Pastores dabo vobis najdobitniej świadczy o tym, w jakim duchu Urząd Nauczycielski Kościoła towarzyszył i nadal towarzyszy prezbiterom, dźwigającym na co dzień ciężar pasterskich obowiązków związanych z wprowadzaniem w życie programu soborowej odnowy wśród społecznego i kulturowego zamętu współczesności. Można powiedzieć, że po Soborze nie było wystąpienia Kościelnego Magisterium, które by w jakiejś mierze nie

${ }^{28}$ List pasterski do katolików Irlandii, s. 8.

29 Tamże.

${ }^{30}$ Por. J. Ratzinger, Moje życie. Wspomnienia z lat 1927-1977, tłum. W. Wiśniowski, Częstochowa 1998, s. 113. 
uwzględniał, wprost lub pośrednio, wsparcia prezbiterów światłem i mocą Ewangelii w interpretacji sytuacji, w jakiej wypada im pełnić powierzone posłannictwo (por. PDV 3). To magisterialne „ewangeliczne rozeznanie” rozbudzało $\mathrm{w}$ ich sercach wiarę, że potrafią stawić czoło trudnościom nowej epoki historycznej pod warunkiem odważnego odczytania i wielkodusznego podjęcia zawartych w niej pastoralnych wyzwań - szczególnie „duszpasterskiego nawrócenia”31.

\section{NAWRÓCENIE DUSZPASTERSKIE PREZBITERA}

Postulat „duszpasterskiego nawrócenia” ukierunkowuje misyjnie program „nowej ewangelizacji”. Wobec wyzwań współczesności funkcjonujący obecnie model parafialnego duszpasterstwa, skoncentrowany na obsłudze stopniowo malejącej liczby praktykujących wiernych, nie sprawdza się. Trzeba koniecznie dokonać przejścia od duszpasterstwa czysto zachowawczego do duszpasterstwa zdecydowanie misyjnego: „nie możemy dłużej pozostawać w spokoju, w biernym oczekiwaniu, w naszych kościołach” (por. EG 15) ${ }^{32}$. Kościół posłuszny misyjnemu nakazowi Jezusa: „Idźcie i nauczajcie wszystkie narody, udzielając im chrztu w imię Ojca i Syna, i Ducha Świętego. Uczcie je zachowywać wszystko, co wam przykazałem” (Mt 28, 19-20) musi być Kościołem „wyruszającym w drogę” (por. EG 21). Nie może koncentrować się wyłącznie na sobie, ubolewać nad swoją sytuacją, uskarżać się na trudności lub dla odmiany popadać w zachwyt nad sobą. Kościół skupiony na sobie jest Kościołem chorym (por. EG 41). O zdrowiu Kościoła świadczy stan permanentnej misji (por. EG 25) ${ }^{33}$.

Pastoralnym priorytetem owego „wyjścia” powinno być głoszenie ewangelicznego orędzia tym, którzy stoją z dala od Chrystusa. Tacy ludzie

${ }^{31}$ Por. M. Polak, Prezbiterologia, s. 46-50.

32 Por. W. Kasper, Papież Franciszek. Rewolucja czułości i miłości. Korzenie teologiczne i perspektywy duszpasterskie, tłum. K. Markiewicz, Warszawa 2015, s. 72-73; K. Kaproń, Kościót, s. 86-87.

33 Por. D. Lipiec, Duszpasterstwo misyjne w nauczaniu papieża Franciszka, w: Duszpasterstwo w świetle nauczania papieża Franciszka, red. D. Lipiec, Lublin 2015, s. $18-22$. 
zaś są nie tylko na geograficznych „krańcach ziemi” (por. Dz 1,8), ale wszędzie, gdzie Kościół istnieje. Stąd też - jak wyraża się papież - „działalność misyjna stanowi paradygmat każdego dzieła Kościoła" (por. EG 15), w tym również duszpasterstwa parafialnego. Kościół „wyruszający w drogę” z ewangelicznym orędziem skierowanym do tych, którzy „potrzebują lekarza” (por. Mt 9, 12) musi być Kościołem „otwartych drzwi”, „ojcowskim domem, gdzie jest miejsce dla każdego z jego trudnym życiem”, a nie „urzędem celnym” z „kontrolerami łaski” (EG 47) 34 .

Pastoralny program nacechowany misyjnym dynamizmem „wyjścia” w pierwszym rzędzie oznacza „wyjście z własnej wygody” (por. EG 20). Dlatego właśnie jest potrzebne „duszpasterskie nawrócenie”. Prezbiter „wyruszający w drogę" musi bowiem niejednokrotnie zdobyć się na odwage porzucenia dotychczasowych przyzwyczajeń oraz tego, co dawało mu fałszywe poczucie bezpieczeństwa: bo przecież „coś” robił i w końcu „ktoś” z tego korzystał. Pierwszym krokiem na drodze tak rozumianego nawrócenia jest zdecydowane "nie” wypowiedziane przesadnej trosce o osobistą przestrzeń autonomii i odprężenia, egoistycznej acedii paraliżującej misyjny entuzjazm i radość głoszenia Ewangelii, stylowi życia skoncentrowanemu na dążeniu do zapewnienia sobie bezpieczeństwa materialnego, kariery i ludzkiej chwały, a w końcu i jałowemu pesymizmowi tłumiącemu ewangelizacyjne zaangażowanie i zapał (por. EG 78-84) ${ }^{35}$.

W postulacie „duszpasterskiego nawrócenia” chodzi nie o jakąś strategię, ale o zwyczajne naśladowanie Chrystusa, o wierność postawie, jaką On pragnie zaszczepić tym wszystkim, którym powierza swoje ewangeliczne orędzie, które nade wszystko jest orędziem Bożego miłosierdzia. "Metodologia duszpasterska”36, będąca owocem owego „nawrócenia” opiera się na ewangelicznych przypowieściach o miłosiernym Ojcu i miłosiernym Samarytaninie (por. Łk 10, 30-37; 15, 11-32). W ich świetle właśnie Kościół ma być „otwartym domem”, który przyjmuje swoje mar-

34 Por. M. Polak, Pedagogia ewangelizacji na przedpolach wiary, w: Peryferie wiary wyzwaniem dla Kościoła, red. W. Przygoda, M. Fiałkowski, Lublin 2015, s. 61-82.

${ }_{35}$ Por. W. Przygoda, Wspótczesne wyzwania pastoralne dla prezbiterów, w: Duszpasterstwo w Polsce. 50 lat inspiracji Soboru Watykańskiego II, red. M. Fiałkowski, Lublin 2015, s. 97-98.

36 Por. M. Polak, Duszpasterstwo miłosierdzia. Miłosierdzie jako paradygmat pastoralnej misji Kościoła, „Teologia Praktyczna” 15 (2014), s. 7-21. 
notrawne dzieci i z którego nieustannie trzeba wychodzić, aby szukać zagubionych i poranionych braci (por. EG 46), gdyż „misją Kościoła jest głoszenie miłosierdzia Boga, bijącego serca Ewangelii”" ${ }^{37}$.

W zarysowanym kontekście jawi się pilna potrzeba „duszpasterskiego nawrócenia” obejmującego prezbiterialną posługę w konfesjonale, stanowiącą najbardziej elementarne misyjne „wyjście” z orędziem Bożego miłosierdzia ku tym, którzy „mają się źle” (por. Mt 9, 12). W ramach tej posługi „otwiera się - jak wyraził się Jan Paweł II - odpowiednia przestrzeń dla Bożego miłosierdzia wobec grzechu człowieka, który się nawraca, oraz do wyrozumiałości wobec ludzkiej słabości” (por. VS 104). Jeśli jednak zabraknie pasterskiej gorliwości cierpliwego i ofiarnego oczekiwania na penitentów w ramach regularnych dyżurów spowiedniczych owa „przestrzeń Bożego Miłosierdzia” zostanie niebezpiecznie ograniczona. Tymczasem taka właśnie tendencja w okresie posoborowym ujawniła się niemal w całym Kościele. Nie można nie zdawać sobie sprawy z tego, że narastający we współczesnym świecie proces zanikania poczucia grzechu pozostaje w ścisłym - niekiedy wręcz genetycznym - związku z fenomenem „opustoszałych” konfesjonałów, a nierzadko także z ich „ewakuacją” ze świątynnej przestrzeni ${ }^{38}$.

Benedykt XVI dał wyraz przekonaniu, że "nowa ewangelizacja” zaczyna się nie gdzie indziej, jak w konfesjonale, bo nawrócenie serca „jest «siłą napędową» wszelkiej reformy”, a jako takie staje się też „prawdziwą siłą ewangelizacyjną" ${ }^{39}$. Zależy to jednak nie tylko od dyspozycyjności spowiedników, ale i od tego, czy i w jakim stopniu okażą się oni zwiastunami Bożego miłosierdzia. Jan Paweł II mówił o potrzebie „wyrozumiałości wobec ludzkiej słabości” i tłumaczył, że jakkolwiek taka postawa „nie oznacza nigdy zniekształcenia ani zafałszowania miary dobra i zła w celu dostosowania jej do okoliczności” (por. VS 104), to jednak zakłada ona również „głęboki i szczery szacunek, ożywiony cierpliwością i ufną miłością, jakiej stale potrzebuje człowiek na swej drodze moralnej,

37 Franciszek, Bulla Misericordiae vultus ogłaszająca Nadzwyczajny Jubileusz Miłosierdzia (8.12.2015-20.11.2016), nr 12.

38 Por. M. Polak, Prezbiterologia, s. 78-80.

39 Por. Benedykt XVI, Spowiedź sakramentalna siła nowej ewangelizacji. Przemówienie do uczestników kursu dla spowiedników (9.03.2012), „L’Osservatore Romano" wyd. polskie 33 (2012) 5, s. 47-48. 
często uciążliwej na skutek trudności, słabości i bolesnych sytuacji” (por. VS 95). Aby skutecznie zadośćuczynić tym dwom na pozór sprzecznym zaleceniom, trzeba $\mathrm{w}$ miejsce bezdusznego egzekwowania norm moralnych, bądź ich lekceważenia podjąć długofalowy trud stopniowego i konsekwentnego wychowywania penitentów do wielkodusznego kroczenia drogą permanentnego nawracania się. Kluczową jest tu postawa duszpasterskiej odpowiedzialności:

Ani kapłan nadmiernie tolerancyjny, ani rygorysta nie dają świadectwa o Jezusie Chrystusie, ponieważ ani jeden ani drugi nie bierze odpowiedzialności za osobę, którą spotyka. Nadmiernie surowy umywa ręce: $\mathrm{w}$ istocie przygważdża ją do prawa pojmowanego w sposób zimny i sztywny; nadmiernie tolerancyjny też umywa ręce: tylko na pozór jest miłosierny [...]. Prawdziwe miłosierdzie bierze odpowiedzialność za osobę, wysłuchuje jej uważnie, podchodzi z szacunkiem i w prawdzie do jej sytuacji i towarzyszy jej w drodze pojednania ${ }^{40}$.

Program „nowej ewangelizacji” zakłada również „nawrócenie duszpasterskie” w wymiarze instytucjonalnym. „Opcja misyjna” powinna przemieniać wszystkie struktury kościelne, aby i one stawały się „odpowiednią drogą bardziej do ewangelizowania współczesnego świata, niż do zachowania stanu rzeczy" (por. EG 27). Dzieje parafii dowodzą, że charakteryzuje się ona dużą elastycznością i otwartością na ewangelizacyjne „znaki czasu”. Adhortacja apostolska Evangelii gaudium w oparciu o „ewangeliczne rozeznanie” współczesnej sytuacji Kościoła wskazuje na potrzebę przekształcenia parafialnego systemu w taki sposób, aby stał się on centrum pobudzającym i formującym wiernych do kreatywności misyjnej (por. EG 28). Oznacza to przebudowę parafii we „wspólnotę wspólnot", ale w oparciu o grupy rodzin zamieszkujących jej terytorium. Nie wchodzi tu zatem w grę powoływanie do życia wspólnot nowych, powiązanych identyczną formą przeżywania wiary, podobnym oglądem rzeczywistości, przekonań czy zainteresowań. Istotne znaczenie ma również ożywienie duchem misyjnym już istniejących wspólnot rodzinnych,

${ }^{40}$ Franciszek, Żyjemy w epoce miłosierdzia. Spotkanie z kapłanami diecezji rzymskiej (6.03.2014), „L'Osservatore Romano” wyd. polskie 35 (2014) 3-4, s. 30-31. 
powiązanych nie tylko terytorialną bliskością, ale i odpowiedzialnością za ewangelizacyjną misję Kościoła (por. FC 70) ${ }^{41}$.

Papież Franciszek postrzega duszpasterstwo rodzin w kontekście „nawrócenia misyjnego”, którego owocem jest odejście od głoszenia czysto teoretycznego i wyizolowanego od rzeczywistych problemów małżonków i rodzin. W tym kontekście zwraca uwagę na upodmiotowienie duszpasterskie rodzin. Stwierdza, że „rodziny chrześcijańskie są głównymi podmiotami duszpasterstwa rodzinnego, zapewniając nade wszystko "radosne świadectwo małżeństw i rodzin, Kościołów domowych»" ${ }^{42}$. To świadectwo jest niezbędne między innymi w tym celu, aby w duszpasterstwie rodzin odejść od przedstawiania tylko „jakichś norm”, a zwrócić się w stronę „Zaproponowania wartości” (por. AL 201) ${ }^{43}$.

Istotną kwestią, która była przedmiotem dyskusji synodalnych i znalazła swoje odzwierciedlenie w posynodalnej adhortacji jest duszpasterstwo rodzin w „sytuacjach nieregularnych” (por. AL 291-312). Metodę duszpasterską adekwatną do tych sytuacji, jaką zaleca papież Franciszek można określić następującymi słowami: „towarzyszyć, rozpoznać i włączyć to, co kruche”. Kościół zawsze „proponuje doskonałość i zachęca do pełniejszej odpowiedzi Bogu”, jednak „musi bacznie i z troską towarzyszyć swoim dzieciom najsłabszym, naznaczonym miłością zranioną i zagubioną, przywracając nadzieję i zaufanie” (por. AL 291). Jednym z podstawowych zadań tak rozumianego towarzyszenia jest „rozeznanie duszpasterskie”. Uwzględnia ono różnorodność i złożoność sytuacji oraz wyraża się w rozeznaniu osobistym i duszpasterskim „indywidualnych przypadków, które powinno uznać, że ponieważ «stopień odpowiedzialności nie jest równy w każdym przypadku», to konsekwencje lub skutki danej normy niekoniecznie muszą być takie same" (por. AL 300). Konsekwencją rozeznania duszpasterskiego, niezależnie od jego rezultatów,

${ }^{41}$ Jan Paweł II, Adhortacje apostolska Familiaris consortio o zadaniach rodziny w świecie współczesnym (1981), nr 70. Por. J. Goleń, Tworzenie wspólnot rodzin, w: Duszpasterstwo rodzin. Refleksja naukowa i działalność pastoralna, red. R. Kamiński i in., Lublin 2013, s. 432-443.

${ }^{42}$ Franciszek, Adhortacja apostolska Amoris laetitia o miłości w rodzinie (2016), nr 200 (dalej skrót: AL).

${ }^{43}$ Por. W. Kasper, Papież Franciszek. Rewolucja czułości i miłości. Korzenie teologiczne i perspektywy duszpasterskie, tłum. K. Markiewicz, Warszawa 2015, s. 70-72. 
jest zaproponowanie drogi „miłosierdzia i integracji” (AL 296), inaczej mówiąc przyjęcie „logiki integracji” (AL 299) oraz „logiki miłosierdzia duszpasterskiego" (AL 307-312). Jedną z ważnych konsekwencji tych postaw duszpasterskich jest potrzeba rozeznania, „które $\mathrm{z}$ różnych form wykluczenia obecnie praktykowanych w dziedzinie liturgicznej, duszpasterskiej, edukacyjnej oraz instytucjonalnej można przezwyciężyć" (por. AL 299) ${ }^{44}$.

Duszpasterstwo parafialne nie jest tylko sprawą kapłanów, ale z pewnością mają oni decydujący wpływ na jego kształt. Trudno sobie wyobrazić, aby jakieś inicjatywy duszpasterskie, a tym bardziej odnowa duszpasterska dokonywały się bez proboszcza, czy wbrew jego woli. Stąd należy przyjąć tezę, że rozwój parafii i prowadzonego w niej duszpasterstwa $\mathrm{w}$ największym stopniu zależy od parafialnego prezbiteratu, a zwłaszcza od proboszcza. Współczesne nauczanie Kościoła odczytujące i interpretujące „znaki czasu” sformułowało dwa pastoralne imperatywy: „nowej ewangelizacji” i „duszpasterskiego nawrócenia”. Niniejszy artykuł starał się wskazać na konieczność „duszpasterskiego nawrócenia” prezbiterów, jako na konieczny warunek odnowy parafialnego duszpasterstwa w duchu „nowej ewangelizacji”.

\section{BIBLIOGRAFIA}

Baniak J., Rezygnacja $z$ kaptaństwa i wybór życia małżeńsko-rodzinnego przez księży rzymskokatolickich $w$ Polsce, Kraków 2001.

Baniak J., Czynniki kryzysu tożsamości kapłańskiej wśród księży rzymskokatolickich w Polsce, „Teologia Praktyczna” 8 (2007), s. 209-264.

Benedykt XVI, List pasterski do katolików Irlandii (19.03.2010), „L'Osservatore Romano” wyd. polskie 31 (2010) 5, s. 7-8.

Benedykt XVI, Spowiedź sakramentalna siła nowej ewangelizacji. Przemówienie do uczestników kursu dla spowiedników (9.03.2012), „L'Osservatore Romano” wyd. polskie 33 (2012) 5, s. 47-48.

Franciszek, Adhortacja apostolska Amoris laetitia o miłości w rodzinie (2016).

Franciszek, Adhortacja apostolska Evangelii gaudium o głoszeniu Ewangelii we współczesnym świecie (2013).

Franciszek, Bulla Misericordiae vultus ogłaszająca Nadzwyczajny Jubileusz Miłosierdzia (8.12.2015-20.11.2016).

${ }^{44}$ Por. M. Polak, Prezbiterologia, s. 83-84. 
Franciszek, Żyjemy $w$ epoce miłosierdzia. Spotkanie z kapłanami diecezji rzymskiej (6.03.2014), „L'Osservatore Romano” wyd. polskie 35 (2014) 3-4, s. 30-31.

Goleń J., Tworzenie wspólnot rodzin, w: Duszpasterstwo rodzin. Refleksja naukowa i działalność pastoralna, red. R. Kamiński, i.in., Lublin 2013, s. 432-443.

Instytut Statystyki Kościoła Katolickiego SAC, Annuarium Statisticum Ecclesiae in Polonia AD 2018, oprac. W. Sadłoń, Warszawa 2018: http://iskk.pl/images/stories/Instytut/ dokumenty/Annuarium_Statisticum_2018.pdf [dostęp:10.12.2018].

Instytut Statystyki Kościoła Katolickiego SAC, Główny Urząd Statystyczny, Kościół Katolicki $w$ Polsce 1991-2011, Warszawa 2014: file://C:/Users/MP/Downloads/ rs_kosciol_katolicki_1991-2011.pdf [dostęp: 10.12.2018].

Jan Paweł II, Adhortacja apostolska Christifideles laici o powołaniu i misji świeckich w Kościele i świecie (1998).

Jan Paweł II, Adhortacja apostolska Pastores dabo vobis o formacji kapłanów we współczesnym świecie (1992).

Jan Paweł II, Adhortacja apostolska Reconciliatio et paenitentia o pojednaniu i pokucie w dzisiejszym posłannictwie Kościoła (1984).

Jan Paweł II, Adhortacje apostolska Familiaris consortio o zadaniach rodziny w świecie współczesnym (1981).

Jan Paweł II, Encyklika Veritatis splendor o niektórych podstawowych problemach nauczania moralnego Kościoła (1993).

Jan Paweł II, Nowa ewangelizacja, postęp człowieka, kultura chrześcijańska (12.10.1992), „L'Osservatore Romano” wyd. polskie 13 (1992) 12, s. 22-29.

Jan Paweł II, List apostolski Tertio Millennio adveniente (1994).

Kaproń K., Kościół, który się nawraca, „Więź” 56 (2013) 4, s. 84-90.

Kasper W., Papież Franciszek. Rewolucja czułości i miłości. Korzenie teologiczne i perspektywy duszpasterskie, tłum. K. Markiewicz, Warszawa 2015.

Kasper W., Papież Franciszek. Rewolucja czułości i miłości. Korzenie teologiczne i perspektywy duszpasterskie, tłum. K. Markiewicz, Warszawa 2015.

Kelm M., Jak przerwać spiralę grzechu? Prawo kościelne wobec pedofilii duchownych, „Więź” 54 (2011) 8-9, s. 55-62.

Kodeks Prawa Kanonicznego (1983).

Lipiec, Duszpasterstwo misyjne w nauczaniu papieża Franciszka, w: Duszpasterstwo $w$ świetle nauczania papieża Franciszka, red. D. Lipiec, Lublin 2015, s. 9-23.

Makowski T., Postulat odnowy parafii w kontekście pastoralnych wyzwań nowej ewangelizacji, „Studia Gnesnensia” 21 (2007), s. 169-222.

Martin D., Krzywda, nadzieja, uzdrowienie. Osobista droga biskupa przez skandale seksualne, „Więź” 54 (2011) 8-9, s. 24-35.

Paweł VI, Encyklika Ecclesiam suam o drogach, którymi Kościół Katolicki powinien kroczyć w dobie obecnej przy pełnieniu swej misji (1964).

Polak M., Prezbiterologia pastoralna. Pastoralna tożsamość współczesnego prezbitera, Poznań 2016.

Polak M., Pedagogia ewangelizacji na przedpolach wiary, w: Peryferie wiary wyzwaniem dla Kościoła, red. W. Przygoda, M. Fiałkowski, Lublin 2015, s. 61-82. 
Polak M., Duszpasterstwo miłosierdzia. Miłosierdzie jako paradygmat pastoralnej misji Kościoła, „Teologia Praktyczna” 15 (2014), s. 7-21.

Polak M., Od teologii do eklezjologii pastoralnej. Zagadnienia fundamentalne, Poznań 2014.

Program nieużywany. Z prof. Wojciechem Giertychem OP, Teologiem Domu Papieskiego rozmawia Roman Bielecki OP, „W Drodze” 2018 (542) 10, s. 46-59.

Przygoda W., Wspótczesne wyzwania pastoralne dla prezbiterów, w: Duszpasterstwo $w$ Polsce. 50 lat inspiracji Soboru Watykańskiego II, red. M. Fiałkowski, Lublin 2015, s. 75-99.

Ratzinger J., Moje życie. Wspomnienia z lat 1927-1977, tłum. W. Wiśniowski, Częstochowa 1998.

Seewald P., Światłość świata. Papież, Kościół i znaki czasu, tłum. P. Napiwodzki, Kraków 2011.

Sobór Watykański II, Konstytucja dogmatyczna Lumen gentium o Kościele (1964).

Strzelczyk G., Odejścia, wierność i oślica Balaama, „Więź” 50 (2007) 6, s. 32-39.

VII Konferencja Ogólna Episkopatu Ameryki Łacińskiej, Aparecida. Jesteśmy uczniami i misjonarzami Jezusa Chrystusa, Warszawa 2014.

Wielebski T., Nawrócenie pastoralne i duszpasterstwo misyjne w Polsce, w: Polska krajem misyjnym? 1050 lat chrześcijaństwa $w$ Polsce, red. P. Ochotny i in., Warszawa 2016, s. $127-168$. 